\title{
Effect of lactobacilliprobiotic strains on IFN- $\gamma$, IL-2 and TNF- $\alpha$ - production in the peripheral blood cells culture of clinically healthy donors
}

\author{
Viktoria V Mokrozub*, Lidia P Babenko, Olena Yu Sokolvyak, Liudmyla M Lazarenko, Mykola Ya Spivak \\ From EPMA-World Congress 2013 \\ Brussels, Belgium. 20-21 September 2013
}

\section{Introduction}

The concept of using Lactobacillus species for disease treatment and prevention as well as health restoration and maintenance is not new. Probiotics have been used therapeutically to modulate immunity, lower cholesterol, treat rheumatoid arthritis, prevent cancer, improve lactose intolerance, and prevent or reduce the effects of atopic dermatitis, Crohn's disease, diarrhea, and constipation as well as candidiasis and urinary tract infections.

\section{Aim}

was study the ability of L. acidophilus IMV B-7279 and L. delbrueckii subsp. bulgaricus IMV B-7281 probiotic strains to influence on Th1-type cytokines production.

\section{Methods}

Experimental studies were performed on blood of clinically healthy donors (females, 26 year old). Venous blood was diluted in a ratio 1:4 of cell medium RPMI1640. Cytokines were induced in diluted blood $500 \mu \mathrm{l}$ via PHA $500 \mu \mathrm{l}(40 \mu \mathrm{g} / \mathrm{ml})$. Ability of peripheral blood cells to produce IFN- $\gamma$ and IL-2 was studied via added probiotic strains $\left(5 \times 10^{9}\right.$ cells $\left./ \mathrm{ml}\right)$ into diluted blood. Cytokines level were investigated in cells supernatants via IFA-method.

\section{Results}

Thus, the ability of peripheral blood cells to produce IFN- $\gamma$ and IL-2 was increased under the influence of $L$. delbrueckii subsp. bulgaricus IMV B-7281. The concentration of IFN- $\gamma$ in the culture medium increased to $322.4 \pm 7.5 \mathrm{pg} / \mathrm{ml}$ against $123.2 \pm 13.8 \mathrm{pg} / \mathrm{ml}(p<0.05)$

\footnotetext{
* Correspondence: vika_mokrozub@mail.ru

D.K. Zabolotny Institute of microbiology and virology, National Academy of Sciences of Ukraine, 154, Zabolotny st., 03680, Kyiv, Ukraine
}

in control; IL-2 - $39.3 \pm 1.1 \mathrm{pg} / \mathrm{ml}(10.4 \pm 1.7 \mathrm{pg} / \mathrm{ml}$ in control; $p<0.05)$. L. acidophilus IMV B-7279 had no activating effect on the production of these cytokines by means of peripheral blood cells. The concentration of IFN- $\gamma$ in the culture medium was $147.3 \pm 15.9 \mathrm{pg} / \mathrm{ml}$ $(p>0.05)$, and IL-2 was at the control level $(11.5 \pm 1.3$ $\mathrm{pg} / \mathrm{ml} ; p>0.05)$.

\section{Conclusion}

The results of our study suggested that $L$. acidophilus IMV B-7279 and L. delbrueckii subsp. bulgaricus IMV B7281 probiotic strains have no activating effect on production of TNF- $\alpha$. The concentration of this cytokine in the culture medium of peripheral blood cells, which were treated with L. acidophilus IMV B-7279 or L. delbrueckii subsp. bulgaricus IMV B-7281, amounted to $8.7 \pm 0.1$ and $8.9 \pm 0.3 \mathrm{pg} / \mathrm{ml}$ against $8.5 \pm 0.5 \mathrm{pg} / \mathrm{ml}$ in control $(p>0.05)$. L. delbrueckii subsp. bulgaricus IMV B-7281 probiotic strain induced in vitro production of Th1-type cytokines in the culture of peripheral blood cells.

\section{Recommendations}

Therefore, this strain is prospective for correction of immune response in infectious and other diseases with clinically unfavorable course accompanied by inhibition of Th1-type T-helpers/inductors.

Published: 11 February 2014

doi:10.1186/1878-5085-5-S1-A135

Cite this article as: Mokrozub et al:: Effect of lactobacilliprobiotic strains on IFN- $\gamma$, IL-2 and TNF- $\alpha$ - production in the peripheral blood cells culture of clinically healthy donors. EPMA Journal 2014 5(Suppl 1):A135. 